\title{
Podlaskie Voivodeship as an opportunity for the development of the BRI in Europe
}

\author{
JOANNA GNIEDZIEJKO \\ Department of Engineering Management \\ Bialystok University of Technology \\ 45A, Wiejska Street, Bialystok \\ POLAND \\ ŁUKASZ RYBIŃSKI \\ Department of Engineering Management \\ Bialystok University of Technology \\ 45A, Wiejska Street, Bialystok \\ POLAND
}

\begin{abstract}
This study aims to evaluate Podlaskie Voivodeship as an important element for the development of the Belt and Road Initiative, by identifying both the internal environment (in terms of strengths and weaknesses) as well as the external environment (in the context of opportunities and threats) of Podlaskie Voivodeship. The study was conducted using critical literature analysis, logical construction method, and SWOT analysis. The authors of the study identified and assessed the strengths and weaknesses of Podlaskie Voivodeship related to the development of the logistics infrastructure of the voivodeship in the light of the Belt and Road Initiative and the opportunities and threats associated with it. Factors of Podlaskie Voivodeship indicated in the article can influence the course of action to increase the competitive advantage of Podlaskie Voivodeship regarding the development of the Belt and Road Initiative in Europe. The study includes a comprehensive SWOT analysis of the Podlaskie Voivodeship in the context of the Belt and Road Initiative. Elements analyzed by the authors may have a significant impact on the development of the voivodeship's infrastructure network regarding the expansion of the BRI.
\end{abstract}

Key-Words: Podlaskie Voivodeship, the Belt and Road Initiative, SWOT

Received: January 4, 2020. Revised: June 26, 2020. Accepted: January 2, 2021. Published: January 23, 2021

\section{Introduction.}

It is important for the Chinese Belt and Road Initiative to collaborate with partners who will help and will facilitate access to Europe, resulting from the assumptions of the program initiated in 2013. In this way, Beijing wants to establish and expand political, trade and infrastructure cooperation, as well as establish contacts between nations. For this purpose, it is important to create and develop routes linking Asia and Europe.

From the logistic point of view, Poland may become an important element for the development of the BRI. In this case, the route that would connect China with Europe is the land route, i.e., the rail route. One of the most optimal alternatives, taking into account the location of Poland, is the Northern Corridor. The route uses the Russian Trans-Siberian Line, starts in Kazakhstan and connects with Russia. The corridor reaches Belarus and passes through Poland as a point connecting Europe. It covers the smallest number of countries and consequently crosses a small number of border crossings ([1];[2]). Poland is an ideal country for the Belt and Road Initiative to develop in Europe. In Poland, most goods from China pass through the Terespol - Brest border crossing, which accounts for over $90 \%$ of transhipments. Other terminals are currently being prepared, which will relieve the above-mentioned border crossing [3]. An example of this is the large shipment of products that arrived from China to Poland on January 5, 2020. The train in which the goods were delivered consisted of 45 containers and crossed the countries of China, Kazakhstan, Russia, Ukraine, and Poland (through the border crossing Izov / Hrubieszów) within 12 days [4]. This shows that it is possible to effectively create a railway route connecting China and Europe.

Poland, however, does not fully use the logistics potential, because there are many border crossings which are not fully used or not used at all. Considering the location, an important region 
through which the BRI route could pass is Podlaskie Voivodeship.

The aim of the article is to assess the potential of the Podlaskie Voivodeship as an important element in the development of the Belt and Road Initiative. Considering the voivodeship's location based on the expansion of the BRI, factors that may affect the development of the trail in Poland were analyzed. For this purpose, the authors identified internal and external factors that may influence the development of the initiative in the region.

The Podlaskie Voivodeship is located in northeastern Poland and is located on the border with Belarus. The region is ideally located and connects the European Union and the Eurasian Economic Union, this demonstrates great logistics potential. Location determines numerous features and phenomena occurring in the region, such as social capital, investment attractiveness, innovation, natural and landscape capital, etc., thanks to that the voivodship is being developed. However, Podlasie does not fully use the infrastructure potential and border crossings. This applies above all to railway routes, which are largely unused or require modernization.

\section{Literature review}

Economic Unions are key, because the BRI land route covers most of the Central Asian territories belonging to the EAEU, which is also a road to Europe [5]. Eurasian space is of strategic importance for Russia and China, which is why the political leaders of these world powers decided to develop, strengthening and expanding cooperation in the field of the economy. The integration of the EAEU and the BRI opens wide opportunities for all participants to develop the economy, modernize technology, create and improve transport and logistics infrastructure. The interests of Russia and China largely overlap, not only of an economic nature, but also related to Eurasia security issues. The first beneficial projects signed in the framework of cooperation between the EAEU and the BRI are aimed at developing transport infrastructure and financial assistance for Member States. In the context of globalization, cooperation between the EAEU and the BRI may be the first step towards creating a large international economic structure [6]. Russia also has reasons to join the Chinese initiative. The main purpose of Russian policy is spreading economic influence, while balancing the acquisition of superpower in Eurasia by the Chinese authorities. However, there are restrictions that hinder the integration of the EAEU and the BRI, such as trade barriers, political tensions, and fears of strong partners inherent in post-Soviet and less developed countries [7]. Despite potential problems, joining the EAEU and the BRI could be the most ambitious initiative in Asia. It can be said that it will certainly benefit, but there are also risks that may affect in particular the EAEU, which is the weaker side [8]. A well-developed plan and assessment of effects is necessary for this integration to make sense. The EAEU and the BRI are effective instruments for the development of the Asian region [9].

An initiative taken by China may increase the trade between the Belt and Road countries, due to reduced transport costs. European Union countries, in particular those that do not have access to the sea, should benefit significantly [10]. However, the vision of China and Europe integration is mixed, because, on the one hand, there is European Union interest in the BRI, enabling the free exchange of goods with China, on the other hand, there is a concern that China will take control over the European market [11]. Europe is still divided between adopting China's growth or maintaining full commitment to its current ally - the United States. For the EU there is also a chance to join the development of the initiative, through the involvement of Central Europe, and thus embed in its own global strategy.

Therefore, it is also in China's interest to adopt a greater European participation in the construction of the BRI, thus giving convenient access to European countries [12].

The Belt and Road Initiative, the European Union and the Eurasian Economic Union projects share certain goals. The EAEU and China have agreed and willingness to develop cooperation, The EU and China are major economic partners and are seeking cooperation opportunities in countries involved in the BRI. One factor for full integration is the lack of EU-EAEU relationship. Although it is rightly assessed that the Eurasian Economic Union is really a Russian geopolitical project, it should not get out of hand. Thanks to appropriate diplomacy and gradual economic cooperation, this would have many benefits for Europe and Asia [13]. Unfortunately, recent years have shown that the conflict between the EU and the EAEU may not end for long, by Ukraine's refusal to accept the EAEU agreement and the simultaneous signing of the Association Agreement with the EU, which directly contributed to Russia's aggressive behavior towards its neighbor, the EU refrained from establishing any formal relations with the EAEU. As Togt indicates, it would be in the EU's best interest to strengthen relations with individual EEU Member States to 
ensure that wider connections throughout Eurasia develop in a sustainable manner and based on international standards [14]. The dialogue between the European Union and the Eurasian Economic Union would remove the barriers on their path to cooperation, giving a better chance of developing the Belt and Road Initiative in Europe [15].

In Poland (as in Europe), some politicians or experts believe that the Chinese initiative is a threat, the second part thinks it's a chance. Poland wants to be seen as a strategic partner for the Belt and Road Initiative, because it gives the opportunity to export products to markets other than European, but also by looking for potential sources of capital it gives the opportunity for further infrastructure development in individual regions [16]. An example of closer cooperation between Poland and China as part of the Belt and Road Initiative is a gradual increase in trade between these countries. Another example is the fact that Poland has signed a Memorandum of Understanding with China as part of the cooperation in the BRI. Of course, Poland's advantage for it to play an important role in the initiative is its location, which stimulated trade between China and Europe [17]. The Polish government encourages Chinese investors to place capital on the Polish market while regulating the protection of Polish resources and means of production. As the author of the article points out about the Polish perspective of the BRI: Cooperation with China should therefore be based on partnership, and not on the total control of the Chinese partner in the entire investment, which is fully financed by it [18].

An example of the fact that Poland could become the main connector (Asia - Europe) of the land routes of the Belt and Road Initiative is the region that connects with Belarus, i.e., a member of the EAEU, is the Podlaskie Voivodeship. This is due to the proposal of the northern corridor (the Northern Corridor), which includes the Trans-Siberian Railway, followed by Russia, Belarus, and Poland, including the Podlasie region. The success of the corridor implementation depends primarily on infrastructure and logistics [19]. Podlasie has the potential for the land route (i.e., by rail) to pass through this region. As data on railway lines in Podlasie show, about $25 \%$ of this territory is in unsatisfactory condition (Resolution of the Podlaskie Voivodship Board, 2018). Decisions to modernize rail and road lines must in some cases be made at the governmental or international level. An additional thing to consider is the border crossings with Belarus, which are being charged towards Poland [20]. Podlaskie Voivodeship is open to new investments, including foreign ones. An example would be the Suwałki Special Economic Zone, where the main communication and transport routes intersect here, leading from north to south and east to west Europe, thus constituting a transport route leading along the eastern border of the EU from Central Europe to Asia.

\section{Methodology}

SWOT analysis was used to conduct the research. The SWOT analysis is widely and mainly used in public units in strategic management. It is a diagnostic tool, that is, it is used at the very beginning of the process of defining strategic plans [21]. SWOT analysis is a tool widely used to analyze the internal and external environment of an organization, region or other object of reflection to understand its situation ([22];[23]). The SWOT analysis is based on a simple classification scheme: all factors affecting the current and future position of the organization are divided into: external to the organization and having the character of internal conditions, and having a negative impact on the organization and having a positive impact [24]. Analysis of the internal environment allows you to analyze all aspects of the analyzed object of consideration, enabling you to identify its strengths and weaknesses [25]. Meanwhile, the analysis of the external environment takes into account the political, economic, social, technological, and competitive environment, allowing to indicate opportunities and threats in the external environment of the object of consideration [25]. The SWOT analysis reveals the current situation of the tested facility and enables the development of future action plans [26]. Conducting SWOT analysis makes it easier for decision-makers to make decisions and create strategies in the context of the development of the analyzed object of consideration.

\section{SWOT analysis results}

This part of the work is used to present the results of the SWOT analysis, whose aim was to identify and analyze the strengths and weaknesses of the Podlaskie Voivodeship related to the development of the logistics infrastructure of the Podlaskie Voivodeship in the light of the Belt and Road Initiative and the opportunities and threats associated with it. The factors listed below are based on analyzes of works, articles and documents related to the Podlaskie Voivodeship, with particular emphasis on the Belt and Road Initiative. All presented internal and external factors are important 
because they visualize the possibility of the development of the BRI route in Europe through the Podlaskie Voivodeship.

\subsection{Strengths of the Podlaskie Voivodeship}

During the SWOT analysis, seven strengths of the Podlaskie voivodeship were identified.

Table 1. Strengths of the Podlaskie Voivodeship

\begin{tabular}{|l|l|}
\hline S1 & $\begin{array}{l}\text { Podlaskie Voivodship has numerous border } \\
\text { crossings with Belarus: 5 roads (including 2 } \\
\text { handling freight traffic: Kuźnica Białostocka- } \\
\text { Bruzgi and Bobrowniki-Bierestowica) and 4 } \\
\text { rails (including 2 serving both normal and } \\
\text { broad-gauge railway traffic, that is Kuźnica } \\
\text { Białostocka-Grodno and Siemianówka- } \\
\text { Świsłocz). }\end{array}$ \\
\hline S2 & $\begin{array}{l}\text { A large share of the railway network enables } \\
\text { trains to move at a speed of at least } 80 \mathrm{~km} / \mathrm{h} \\
\text { for passenger trains (68.5\%) and 60 km / h for } \\
\text { freight trains (81\%), mainly on railway routes } \\
\text { connecting the most important centers of the } \\
\text { region. }\end{array}$ \\
\hline S3 & $\begin{array}{l}\text { Most of the available rail network allows trains } \\
\text { at moving to axle loads of 221 kN / axle, i.e., } \\
\text { 22.5 / axle (59.1\%) or 205 kN / axle, i.e., 20.9 } \\
\text { t/ axle (33.8\%). This means that quite large } \\
\text { tonnage trains can move around the } \\
\text { voivodeship. }\end{array}$ \\
\hline S4 & $\begin{array}{l}\text { Most of the important urban centers of the } \\
\text { Podlasie Voivodship are connected to each } \\
\text { other both by means of the railway network } \\
\text { and the public road network, especially cities } \\
\text { such as Białystok, Sokółka, Suwałki, } \\
\text { Augustów, Bielsk Podlaski, Siemiatycze, } \\
\text { Hajnówka and Łomża. }\end{array}$ \\
\hline S5 & $\begin{array}{l}\text { Logistics centers enable the distribution of } \\
\text { loads located near border crossings, e.g., in } \\
\text { Losośna, near Kuźnica Białostocka, or at the } \\
\text { intersection of the most important } \\
\text { communication routes, e.g. in Białystok. }\end{array}$ \\
\hline S6 & $\begin{array}{l}\text { The density of public roads is 132.1 km / 100 } \\
\text { km2, including hard roads 66.6 km / 100 km2. }\end{array}$ \\
\hline S7 & $\begin{array}{l}\text { Favorably border location of the province } \\
\text { (eastern border of the province at the same } \\
\text { time, part of the eastern border of the European } \\
\text { Union, and the border of two railway systems - } \\
\text { railway network with normal and wide gauge } \\
\text { of tracks). }\end{array}$ \\
So
\end{tabular}

Source. Own elaboration

\subsection{Weaknesses of the Podlaskie Voivodeship} As part of the SWOT analysis, ten weaknesses of the Podlaskie voivodeship were identified.
Table 2. Weaknesses of the Podlaskie Voivodeship

\begin{tabular}{|l|l|}
\hline W1 & $\begin{array}{l}\text { Poor transport and infrastructure } \\
\text { accessibility of the voivodship compared to } \\
\text { other voivodships. }\end{array}$ \\
\hline W2 & $\begin{array}{l}\text { Very low density of the railway network in } \\
\text { the region and a low degree of electrification } \\
\text { and multitrack of the railway network. }\end{array}$ \\
\hline W3 & $\begin{array}{l}\text { Occurrence of bottlenecks related to the } \\
\text { permissible speed, load, and capacity of the } \\
\text { railway network, preventing the use of the } \\
\text { full potential of the railway network. }\end{array}$ \\
\hline W4 & $\begin{array}{l}\text { Missing track sections prevent the use of all } \\
\text { border crossings for cross-border traffic. }\end{array}$ \\
\hline W5 & $\begin{array}{l}\text { Lack of adequate financial resources } \\
\text { necessary to carry out all necessary } \\
\text { infrastructure investments. }\end{array}$ \\
\hline W6 & $\begin{array}{l}\text { Limited cargo handling options in the } \\
\text { Podlaskie Voivodeship. }\end{array}$ \\
\hline W7 & $\begin{array}{l}\text { Outflow of talented and educated staff } \\
\text { towards the capital, including those related to } \\
\text { transport. }\end{array}$ \\
\hline W8 & $\begin{array}{l}\text { Low level of internationalization of Podlasie } \\
\text { entrepreneurs. }\end{array}$ \\
\hline W9 & $\begin{array}{l}\text { Perception of protected areas as a } \\
\text { development barrier, even in relation to the } \\
\text { developing the railway network in the } \\
\text { voivodeship. }\end{array}$ \\
\hline W10 & $\begin{array}{l}\text { Not using all railway lines located in the } \\
\text { Podlaskie Voivodeship in railway traffic. }\end{array}$ \\
\hline S0urce Own
\end{tabular}

Source. Own elaboration

\subsection{Identified opportunities for the Podlaskie Voivodeship}

During the SWOT analysis, seven opportunities for the development of the Podlaskie Voivodeship were identified.

Table 3. Opportunities of the Podlaskie Voivodeship

\begin{tabular}{|l|l|}
\hline O1 & $\begin{array}{l}\text { The region is crossed by international rail } \\
\text { routes: Warsaw - Białystok - Kaunas - Riga - } \\
\text { Tallinn (Rail Baltica), Baranowicze - } \\
\text { Wołkowysk - Białystok, Warsaw - Białystok - } \\
\text { Grodno - Vilnius / Saint Petersburg / Moscow, } \\
\text { Kalinigrad - Białystok - Brest, The Belt and } \\
\text { Road Initiative. }\end{array}$ \\
\hline O2 & $\begin{array}{l}\text { The region is crossed by international road } \\
\text { routes: Warsaw - Ostrów Mazowiecka - } \\
\text { Łomża - Suwałki - Kaunas - Riga - Tallinn } \\
\text { (Via Baltica), Klaipeda - Kaunas - Białystok - } \\
\text { Lublin - Rzeszów - Košice - Debrecen - Sofia - } \\
\text { Thessaloniki (Via Carpatia). }\end{array}$ \\
\hline O3 & Needs related to rational planning of transport \\
\hline
\end{tabular}




\begin{tabular}{|l|l|}
\hline & $\begin{array}{l}\text { between China and Western Europe crossing } \\
\text { the Polish-Belarusian border. }\end{array}$ \\
\hline O4 & $\begin{array}{l}\text { The possibility of obtaining funds from } \\
\text { external sources (e.g., EU) for the } \\
\text { modernization of transport and logical } \\
\text { infrastructure in the Podlaskie Voivodeship. }\end{array}$ \\
\hline O5 & $\begin{array}{l}\text { Development of cross-border cooperation } \\
\text { related to BRI. }\end{array}$ \\
\hline O6 & $\begin{array}{l}\text { EU policy focused on the development of } \\
\text { multimodal transport, supporting the } \\
\text { development of infrastructure in areas } \\
\text { deprived of it. }\end{array}$ \\
\hline O7 & $\begin{array}{l}\text { The increase in demand on eastern markets for } \\
\text { Polish products. }\end{array}$ \\
\hline Sourn
\end{tabular}

Source. Own elaboration

\subsection{Identified threats to the Podlaskie Voivodeship}

During the SWOT analysis, eight threats to the development of the Podlaskie voivodeship were identified.

Table 3. Threats of the Podlaskie Voivodeship

\begin{tabular}{|l|l|}
\hline T1 & $\begin{array}{l}\text { The possibility of directing streams of loads } \\
\text { from China to Western Europe on routes } \\
\text { bypassing the Podlaskie Voivodeship. }\end{array}$ \\
\hline T2 & $\begin{array}{l}\text { Intense competition on the BRI connected with } \\
\text { the takeover of cargo flows. }\end{array}$ \\
\hline T3 & $\begin{array}{l}\text { Chronic and complicated procedures related to } \\
\text { infrastructure modernization and tenders. }\end{array}$ \\
\hline T4 & $\begin{array}{l}\text { Marginalization of the Podlasie Voivodship } \\
\text { resulting from the persistence of poor transport } \\
\text { accessibility. }\end{array}$ \\
\hline T5 & $\begin{array}{l}\text { Closing and / or closing down of railway lines } \\
\text { due to their non-use and deterioration of their } \\
\text { quality. }\end{array}$ \\
\hline T6 & $\begin{array}{l}\text { Political, administrative, and economic } \\
\text { restrictions result in reduced possibilities of } \\
\text { using the region's border location and entering } \\
\text { the eastern market. }\end{array}$ \\
\hline T7 & $\begin{array}{l}\text { Marginalization of the region in the state's } \\
\text { development plans by central authorities; } \\
\text { further delaying the implementation of key } \\
\text { investments for the voivodship. }\end{array}$ \\
\hline T8 & $\begin{array}{l}\text { Political crisis in Belarus, triggered by protests } \\
\text { in connection with the presidential elections } \\
\text { (09/08/2020), is having a negative impact on } \\
\text { international relations, including with Poland. }\end{array}$ \\
\hline
\end{tabular}

Source. Own elaboration

\section{Conclusions}

The Belt and Road Initiative is a project aimed at introducing closer Asia-Europe economic cooperation. Partners are needed for closer integration, who will help develop the initiative. One of such countries is Poland, which is favorable to cooperation.

Research problems concerning the potential of Podlaskie Voivodeship in the development of BRI land routes in Europe. In the authors' opinion, this region, due to its location in the border region of both the European Union and (on the other side of the Polish-Belarusian border) of the Eurasian Economic Union, as well as the condition of the infrastructure network located in its area, it may have a significant impact on the development of rail transport in this area and the directions of cargo flows.

The SWOT analysis allowed for the identification of features that may have a significant impact on the development of the initiative in the Podlaskie Voivodeship. The strengths of the region are primarily transport connections (rail and road) and logistics centers that facilitate the flow of goods. An important fact, repeated many times, is the geographical location of the voivodeship. This region is located in the north-eastern part of Poland, which is a member of the European Union. Podlaskie Voivodeship borders with Belarus, which is a member of the Eurasian Economic Union. Due to the interest in the Belt and Road Initiative project by EAEU, Podlasie could contribute to develop the BRI's land routes across Europe and to become a link between the EAEU and the EU. The weakness of Podlasie is the unused logistics and transport potential and less support for the development of the economy compared to other voivodeships. Thanks to integrated and rational actions, the full potential of the region can be used. External and domestic financial resources will allow the modernization of rail and road routes, which will enable more efficient movement of goods. This will allow the Podlaskie Voivodeship to emerge in a wider economic horizon. Despite the development of the region, the modernization process is progressing slowly, especially the railway network. Marginalization of the region by central authorities and procedural difficulties may lead to delays in investment implementation. Currently, the COVID19 virus has paralyzed the whole world and has affected the economies of countries, including Poland, which has to some extent affected the Podlaskie Voivodeship. International relations have an impact on the development of the Belt and Road initiative. The most recent example is Belarus and the political and economic crisis caused by the presidential election and the protests by Belarusians. The Belarusian authorities are accusing Western countries (including Poland) of interfering in the 
country's internal affairs. It can be unequivocally stated, this may have a negative impact on the development of the initiative in Podlasie.

However, at present, it should be noted, Podlaskie Voivodeship is within the interest of both the European Union through the Rail Baltica project and the Far East countries, including China, through the Belt and Road Initiative project. The progressive improvement of the logistics and transport infrastructure of the Podlaskie Voivodeship, and thus the gradual increase in the level of the region's logistics potential, will certainly strengthen the competitiveness of rail connections implemented under the Belt and Road Initiative from the Far East to Western Europe through the Polish-Belarusian border crossings located along the eastern border of the Podlaskie Voivodeship. Therefore, the authors recommend not to abandon the investments planned for the coming years in the current crisis.

Various issues can be addressed in future research. Possible topics for future research include possible positive changes in the infrastructure of Podlaskie Voivodeship, planned modernization works in the area of Podlaskie Voivodeship, or the future of the region's logistics potential in relation to projects implemented in the region, including the Rail Baltica and the BRI.

\section{References:}

[1] Kondybayeva, S., Sadykhanova, G., Mukhamediyev, B. The New Silk Road Economic belt policy: The great chance for the rejuvenation of Europe, Proceedings of the 29th International Business Information Management Association Conference - Education Excellence and Innovation Management through Vision 2020: From Regional Development Sustainability to Global Economic Growth, 2017, pp. 1969-1974

[2] Nazarko J, Kuźmicz KA, Czerewacz-Filipowicz K (2016) The New Silk Road - Analysis of the potential of new Eurasian transport corridors, Faculty of Management, Bialystok University of Technology, pp 1-8

[3] Frączyk J (2019) Polska kluczowa na Jedwabnym Szlaku. Gospodarka zyska aż 48 mld dolarów [Poland is a key on the Silk Road. The economy will gain as much as $\$ 48$ billion] https://www.money.pl/gospodarka/polskakluczowa-na-jedwabnym-szlaku-gospodarkazyska-az-48-mld-dolarow-

6453833918146689a.html. Accessed 2 Sep 2020

[4] Sobierajski P (2020) Nowy Jedwabny Szlak z Chin do Polski oficjalnie otwarty. Powitanie transportu z Chin w Sławkowie [The New Silk Road from China to Poland is officially open. Welcoming transport from China in Sławków], https://dziennikzachodni.pl/nowy-jedwabnyszlak-z-chin-do-polski-oficjalnie-otwartypowitanie-transportu-z-chin-w-slawkowiezdjecia/ar/c1-14701637. Accessed 2 Dec 2019

[5] Shakhanova G and Garlick JA (2020) The Belt and Road Initiative and the Eurasian Economic Union: Exploring "the Greater Eurasian Partnership", Journal of Current Chinese Affairs, 00(0) pp 1-25

[6] Garbuzarova EG (2019) Cooperation between the Eurasian Economic Union and the Silk Road Economic Belt: Benefits, Risks, Achievements, Post-Soviet Issues, Vol.6, No.2, pp 8-15

[7] Konopelko A, Czerewacz-Filipowicz K (2021) The Strategy of the Eurasian Economic Union Extra-Regional Integration, WSEAS Transactions on Business and Economics, Vol. 18, pp 67-77

[8] Alimov R (2018) The Shanghai Cooperation Organisation: Its role and place inthe development of Eurasia, Journal of Eurasian Studies, 9(2), pp 114-124

[9] Mekhdiev E, Pashkovskaya I, Takmakova E, Smirnova O, Sadykova K, Poltorykhina S (2019) Conjugation of the Belt and Road Initiative and Eurasian Economic Union: Problems and Development Prospects, Economies, MDPI, Open Access Journal, Vol.7 No.4, pp 1-15

[10] Grieger G (2016) One Belt, One Road (OBOR):China's regional integration initiative, European Parliamentary Research Service, Members' Research Service, https://www.europarl.europa.eu/RegData/etudes /BRIE/2016/586608/EPRS_BRI(2016)586608_ EN.pdf. Accessed 28 Aug 2020

[11] García-Herrero A, Xu J (2016) China's Belt and Road Initiative: Can Europe Expect Trade Gains?, SSRN Electronic Journal, Issue 5, pp 119

[12] Verlare J, Putten FP (2015) 'One Belt, One Road': An Opportunity for the EU's Security Strategy, Clingendael, Netherlands Institute of International Relations, pp 1-6

[13] Bond I (2017) The EU, the Eurasian Economic Union and One Belt, One Road Can they work together?, Centre for European Reform,

https://www.cer.eu/sites/default/files/pb_eurasia n_IB_16.3.17_0.pdf. Accessed 29 May 2020

[14] Togt T (2020) EU \& Eurasian Economic Union: A Common Chinese Challenge, 
Clingendale - Netherlands Institute of Intenational Relations, https://www.clingendael.org/publication/eueurasian-economic-union-common-chinesechallenge. Accessed 27 May 2020

[15] Czerewacz-Filipowicz K (2019) The Eurasian Economic Union as an Element of the Belt and Road Initiative, Comparative Economic Research. Central and Eastern Europe, Vol.22, No.2, pp 23-37

[16] Pendrakowska P (2019) Poland's perspective on the Belt and Road Initiative, Journal of Contemporary East Asia Studies, Vol.7, No.2, pp 190-206

[17] Meiling C (2017) Poland looking to bolster trade with China under BRI, China Daily. https://www.chinadaily.com.cn/a/201905/28/W S5cec97dca3104842260be305.html. Accessed 27 May 2020

[18] Choroś-Mrozowska D (2019) The Chinese Belt and Road Initiative from the Polish Perspective, Comparative Economic Research. Central and Eastern Europe, 22(2), pp 39-53

[19] Nazarko J, Kuźmicz KA (2017) Introduction to the STEEPVL Analysis of the New Silk Road Initiative, Procedia Engineering, Vol.182, pp 497-503

[20] Kostecka-Tomaszewska L, CzerewaczFilipowicz K (2019) Poland -A Gate to the EU or a Bottleneck in the Belt and Road Initiative, European Research Studies Journal, Vol. 22, No.4, pp 472-492

[21] Asejczyk-Woroniecka M (2016) Zastosowanie analizy SWOT w doskonaleniu zarządzania jednostkami administracji terytorialnej [The use of SWOT analysis in improving the management of territorial administration units], Finanse, Rynki Finansowe, Ubezpieczenia, 6(84), pp 311-321

[22] Wheelen TL, Hunger JD (1995) Strategic Management and Business Policy, 5th Edition, Addison Wesley, Reading, MA

[23] Rodríguez JM, Ventura J (2003) Human Resource Management Systems and Organizational Performance: An Analysis of the Spanish Manufacturing Industry. International
Journal of Human Resource Management, 14(7), pp 1206-1226

[24] Szmitka S (2015) Analiza SWOT jako narzędzie oceny innowacyjności przedsięwzięcia biznesowego [SWOT analysis as a tool for assessing the innovation of a business venture], Wyższa Szkoła Informatyki i Ekonomii TWP

[25] Filipe JA, Genç T (2019) Modelling and Idle Building Case through SWOT Analysis and Fuzzy DEMATEL - A Study on AntiCommons, European Research Studies Journal, Vol.21, No.1, pp 167-185

[26] Gürel E (2017) SWOT analysis: a theoretical review, Journal of International Social Research, 10(51), pp 994-1006

\section{Contribution of individual authors to the creation of a scientific article (ghostwriting policy)}

In this article, the goal formulation, methodology and final conclusions are developed by both authors. The identification of the key factors related to the SWOT analysis was prepared by Joanna Gniedziejko. Gathering the current knowledge related to the subject in the form of a literature review was carried by Łukasz Rybiński.

\section{Funding:}

This work was supported by the Ministry of Science and Higher Education of the Republic of Poland under Grant No. WI / WIZ-INZ / 4 / 2020 and Grant No. WI / WIZ-INZ / 8 / 2020.

\section{Creative Commons Attribution License 4.0 (Attribution 4.0 International , CC BY 4.0)}

This article is published under the terms of the Creative Commons Attribution License 4.0 https://creativecommons.org/licenses/by/4.0/deed.en US. 